
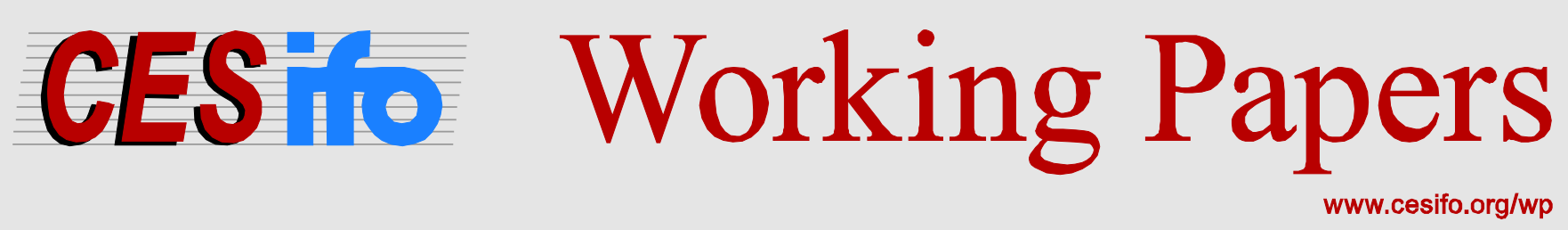

\title{
Teaching and Learning Alternatives to a Comparative Advantage Motivation for Trade
}

\author{
James K. Self \\ William E. Becker
}

CESIFO WORKING PAPER NO. 5238

CATEGORY 5: ECONOMICS OF EDUCATION

MARCH 2015

An electronic version of the paper may be downloaded

- from the SSRN website:

- from the RePEc website:

- from the CESifo website:

WwW.SSRN.com

Www.RePEc.org

www.CESifo-group.org/wp 


\title{
Teaching and Learning Alternatives to a Comparative Advantage Motivation for Trade
}

\begin{abstract}
Introductory economics courses emphasize opportunity cost, comparative advantage and specialization to show the benefits of trade. We assert that this emphasize leads to erroneous student mindset that trade requires specialization based on comparative advantage. We test students who have been exposed to the typical textbook and classroom presentation of specialization and trade with real but paradoxical situations where the same goods are both imported and exported by a country. Students are found to generally understand comparative advantage calculations but wrongfully apply the idea to this multiproduct trade situation for which specialization is not relevant.
\end{abstract}

JEL-Code: A200.

Keywords: comparative advantage, specialization, trade, introductory economics textbooks.

\author{
James K. Self* \\ Department of Economics \\ Indiana University \\ Wylie Hall 105, 100 S. Woodlawn \\ USA - Bloomington, IN 47405-7104 \\ jkself@indiana.edu
}

William E. Becker

Department of Economics

Indiana University

Wylie Hall 105, 100 S Woodlawn

USA - Bloomington, IN 47405-7104

beckerw@indiana.edu

*corresponding author

WORKING DRAFT: January 14, 2015. 


\section{Introduction}

W. E. Becker (2000, 2004, 2007) documents how many basic concepts in economics are improperly presented in textbooks and poorly taught in ways that likely leaves students with misunderstandings of current thinking in economics. Similarly, A. B. Krueger (2001, 2008) has had a longstanding complaint that introductory economics courses have not kept up with advances in the science of economics. Here we demonstrate how the teaching of comparative advantage and specialization as the rationale for trade have not much changed since first articulated by David Ricardo (1772-1823) even though Nobel Prizes have been award for developments in our understanding of trade, see awards given to Bertil Ohlin and James Meade in 1977 and Paul Krugman in 2008 .

In this study, we explore whether students truly understand the idea of comparative advantage as it applies to current real-world trade patterns or are they simply meeting poorly constructed learning objectives. Our hypotheses is that students, after being exposed to the standard teaching practice found in introductory economic courses, will be

1) able to answer a set of questions that are designed to test understanding of comparative advantage calculations, specialization, and trade that replicates conclusions consistent with Ricardo’s environment;

2) unable to recognized how that analysis does not apply to observed patterns of trade in which a country is importing and exporting the same good.

We use several traditional introductory microeconomics courses as a venue to test students' understanding of trade via Test of Understanding of College Economics (TUCE) type hypothetical questions in which bilateral trade is rationalized by comparative advantage. In the same venue we also test students with a question presenting real-world trade flows, as found in Paul Krugman's 2008 Nobel Lecture, that indicate trade of goods moving in both directions for both trading partners. Students who understand comparative advantage should recognize that it cannot be the reason for trade flows that move the same goods in both directions. We find that students do well on answering the traditional TUCE comparative, specialization, and trade questions but do no better than a random guess at the correct answers when answering questions that present a real-world contradiction to the logical patterns of trade for reasons of comparative advantage and specialization alone. When confronted with real world trade involving countries importing and exporting the same goods, student in a non-random manner wrongly continue to select comparative advantage as the reason for trade. 
To assess whether the problem can be traced to textbooks that uniformly leave students with a dilemma between what they have learnt and what is seen in the real-world, we survey the most widely adopted introductory textbooks and establish a similar misleading approach to comparative, specialization, and trade. We find little to no deviation from or caveats to a Ricardian applications of comparative advantage, specialization and trade in many situations far a field of agricultural goods produced in fixed ways. Students are left with the wrong impression that comparative advantage is the only reason for trade and that there have been no advances on this idea in 250 years.

\section{Misapplication of Comparative Advantage to Hypotheticals and Real-Wold Trade}

Berrett (2012) audited three principles of economics courses across a spectrum of tertiary institutions (George Washington University, George Mason University and the University of Phoenix). He found the same core ideas taught in all three courses and focused on the nuances in the teaching of comparative advantage and trade at each of the universities.

At the University of Phoenix the teacher used an adaptation of a comparative advantage example found in past and the current edition of Gregory Mankiw’s Principles of Microeconomics (2015, pages 55-56). A hypothetical trade is motivated between a highly paid athlete and a minimum wage kid because the opportunity cost is too high for the athlete to cut his own grass, even though he has an absolute advantage in physical activities. It is thus better for him to hire the minimum wage kid to cut his grass. The pedagogical approach is to get students to internalize the concept through familiar understanding of other aspects of their lives. It and other contrived examples that move away from the original Ricardo situation of two countries are an attempt to draw inferences between the students' lives and the topic of comparative advantage.

Unrecognized by Berrett in his positive reporting on the University of Phoenix teacher's discussion, is the fact that humans have feelings, tastes and desires unlike inanimate resources. Moving from Ricardo's countries with fixed land, climate and production frontiers to human beings is not so simple. It is possible that the athlete (as does one of the authors of this paper) gets great satisfaction from cutting grass, not being dependent on others, and multitasking (joint production of physical conditioning and grass cutting -- one minute walking behind the lawnmower is one less minute on a treadmill). ${ }^{1}$ Curiously, Gary Becker’s 
1992 Nobel Prize winning work on productive consumption (activities that enhance both utility and wealth) was ignored by Mankiw and the instructor at the University of Phoenix. Is it likely that other instructors who use this type of example involving human being likewise ignore the feelings, tastes and desires of the folks they invoke?

Although Berrett (2012) misses the significance, students at George Washington and George Mason, are reported to be getting examples closer to Ricardo's original illustration, in which a parcel of land is ideally suited for a crop in one country, wheat in Britain, and another piece of land that is suited for something else in another country, such as grapes for wine production in Portugal. Britain (Portugal) has a comparative advantage in wheat (wine) because it is relatively less costly to produce wheat (wine) in Britain (Portugal). If Britain (Portugal) specializes in producing wheat (wine), then both Britain and Portugal will benefit from trade. To assess student mastery of the idea of comparative advantage in these artificial country trade examples, a question such as that appearing on the microeconomics TUCE is typically employed:

TUCE Question 28 (TUCE-28): The table below shows the sums of rice and corn that can be produced in Country $\mathrm{X}$ and Country $\mathrm{Y}$ in one year, using the same amount of productive resources:

$\begin{array}{lll} & \text { Rice } & \text { Corn } \\ \text { Country X } & 20 & 10 \\ \text { Country Y } & 16 & 4\end{array}$

According to the theory of comparative advantage, what should firms in Country $\mathrm{X}$ do?
A. export rice to Country Y and import corn
B. export corn to Country $\mathrm{Y}$ and import rice
C. export both rice and corn to Country Y
D. import both rice and corn from Country Y

However, TUCE-28 and those similar do not reveal information on student understanding of the basic conditions that allow for specialization and comparative advantage driven trade to occur. For example, it does not provide any insight as to student understanding of how trade route difficulties, disinformation, uncertainty and like impediments would need to be overcome in order for choice " $\mathrm{B}$ " to be relevant in the realworld. Students today have experienced rapid change in technologies but yet here they are expected to assume a world with fixed technology. This is not to say that students will get a better grasp of the strengths and limitations of comparative advantage as a reason for trade when taught via contrived country versus human comparisons. It is to say that limitations are 
not being taught or learned. Students might just be memorizing conclusion and not understanding the concept.

The question we ask here is whether students who might be able to answer a contrived questions about comparative advantage (such as TUCE-28) will correctly answer a question about trade for which comparative advantage is not an appropriate driver of the trade pattern? Consider, for example, that comparative advantage cannot be used to explain why Germany imports Peugeot cars from France at the same time it is exporting Volkswagens to France. Yet, this is the nature of much of trade that students actually observe today. Will students who may have mastered the idea of comparative advantage and trade in a contrived situation wrongly attempt to impose the comparative advantage rationale on trade situation where it is not relevant?

Paul Krugman provides the nucleus for our alternative to the TUCE-28 question in his 2008 Nobel Prize lecture ( http://www.nobelprize.org/mediaplayer/index.php?id=1072\&view=1) when he called attention to the fact that comparative advantage cannot be used to explain or criticize a country importing goods like those that it is also exporting. In those cases, consideration must be given to taste, desires and production technologies. Beginning students cannot be expected to understand and appreciate the intricacies of the gravity model of trade, the Leontief paradox, the Linder hypothesis, and other components that led to and are now part of the New Trade Theory. They can and should be made aware, however, that economists recognize the shortcomings of comparative advantage and have alternative models that are consistent with countries trading like goods based on consumers' desires for diversity and producers searching for increasing returns to scale. To test for this awareness we propose the following question and two alternative sets of responses:

Trade Flows One (TF-1): The observation that Germany is importing cars and wine from France as it is exporting cars and wine to France, suggests that these trade patterns are the result of Germany's and France's

A. Differing preference for products that each country's residents demand.

B. Trade agreements prohibiting specialization within the European Union.

C. Equality of opportunity cost in production of their similar products.

D. Respective comparative advantage in the production of their products.

Trade Flows Two (TF-2): The observation that Germany is importing cars and wine from France as it is exporting cars and wine to France, suggests that these trade patterns are the result of Germany's and France's

A. equality of opportunity costs in production of their similar products.

B. respective comparative advantages in the production of their products. 
C. Options A and B are correct.

D. Options A, B and C are not correct.

\section{Data Generation}

Student ability to identify trade patterns that are consistent or inconsistent with comparative advantage is measured by their response to TF- 1 and TF-2. The questions were administered to students at the end of a multi-sections introduction microeconomics course. ${ }^{2}$ The course was taught at Indiana University's Bloomington campus with data generated from four regular semesters. Each course was administratively structured in a traditional 16-week semester, 15 weeks of lectures that are followed by a final examination week.

Indiana University’s Bloomington campus is a large public research institution with approximately 3,200 students enrolling in an introduction to microeconomics course each academic year with a typical drop rate of $18 \%$ by the $9^{\text {th }}$ week, which is the deadline for students to drop a course and receive an automatic "W" on their transcripts. The course sections are an assortment of 200 plus student sections taught by department faculty who specialize in undergraduate instruction and smaller 40 to 60 student sections that are taught by Graduate Student associate instructors. All sections have a common defined set of learning objectives. Concepts of comparative advantage are part of the common learning objectives, where the section instructor decides on the textbook to be employed and the classroom discussed as with the alternatives presented earlier in this article.

The data set contains approximately 3,000 students that were drawn from Fall 2010, Spring 2011, Fall 2011, and Spring 2012 semesters. In addition, we have section specific data for sections taught by the first author, henceforth refer to as "Self.." Self's data are a subset of the overall data set and come from course sections of 200 plus students. A benefit of the section specific data is that the microeconomics preTUCE was administered on the second day of class and postTUCE were administered on the second and last day of the class. ${ }^{3}$ This allows for a comparison of student performance before and after the course lessons.

All instructors who taught the course were required to administer a set of department wide questions as part of their final examination and all students completed their final examination at the same time regardless of which course section they were a member. Of the 
instructors teaching the course, only Self knew of this study. The others only knew of the TF1 and TF-2 in Fall 2010 and Spring 2011, respectively, when the department wide set of final examinations questions were being finalized and then administered to the students at the end of those semesters. This provided a check to see if Self might have inadvertently taught comparative advantage in his sections that was dissimilar to the way it was historically taught.

\section{Results for Trade Flows One (TF-1)}

TF-1 was administered, via the final course exam, to all course sections in Fall 2010. TF-1 provides us with insight into students' ability to identify an alternative reason for trade (option A), in light of distractors (B, C and D) that a student who was relying on comparative advantage as the only reason for trade might select. Answer choice "A,” is the only answer that might produce the stated trade patterns based on diverse product demand and not comparative advantage. Answer choice " $\mathrm{B}$ " is provided to the student as a choice that makes little sense but draws in students who might believe the only way that countries would not follow a Ricardian comparative advantage trade example is if there was government interference. Choice "C" gives those students with an incomplete understanding of comparative advantage a choice that appears to be based on opportunity cost. Choice "D" gives students an option that would most likely attract those students who try to memorize key terms and gives the typical taught reason for trade.

Given the four choices to TF-1, a student that is simply guessing is expected to answer correctly $25 \%$ of the time. In both the aggregate and Self's samples of students this is approximately what happened, with only $25.7 \%$ and $22.7 \%$ of students responded correctly, respectively (Table 1). Students tended to select choice "D” at a rate, $44.8 \%$ for all students and $44.3 \%$ for Self's students, which would not be expected by students who just randomly guessed. Choice " $\mathrm{D}$ ” is the most likely selection for those students that relied on memorization of key words, e.g., comparative advantage. Choice "C" may have drawn some students in but its response rate is similar to a rate expected from random guessing.

The scores from TF-1 support the second part of our hypothesis: students are unable to recognize how that analysis does not apply to observed patterns of trade in which a country is importing and exporting the same good. 


\section{Results for Trade Flows Two (TF-2):}

TF-2 was administered, via the final course exam, to all course sections in Spring 2011. Self's sections in the Fall of 2011 and Spring 2012 again answered TF-2 that was administered as an add on section to their preTUCE and postTUCE.

The main difference between TF-1(Table 1) and TF-2 (Table 2) is that in TF-2 the answer choices were changed to only focus on students having an understanding of the impact on trade patterns that comparative advantage trade reason would generate. It makes no requirement on the student to identify a situation that would generate the trade patterns discussed in the question. TF-1 answer choices " $C$ " and " $D$ " were retained but changed to selections " $A$ " and " $B$ ” respectively. TF-2 answer choice " $C$ " became a choice to attract those students who considered both "A" and "B" to be correct. The correct choice " $D$ " simply said that none of the options explain the trade patterns. That is, comparative advantage cannot explain the stated trade patterns. Here the same results emerged in Spring 2011, Fall 2011, and Spring 2012, with less than 20 percent of all students selecting the correct answer.

The scores from TF-2 support the second part of our hypothesis: students are unable to recognize how that analysis does not apply to observed patterns of trade in which a country is importing and exporting the same good.

\section{Results for Pre and Post TUCE-28}

Table 3 reports the results of Self's students for TUCE-28. We see a similar pattern in each semester. On the preTUCE students answer the question correctly between $22 \%$ and $30 \%$. At the end of the semester on the postTUCE they scored $50 \%$ to $64 \%$ correct. These large gains likely reflect the focus on trade being motivated by comparative advantage as emphasised in the textbook and class lecture. We find that after students complete their introductory course they are able to replicate the calculations used in the typical introductory discussion of comparative advantage and are generally successful in selecting the correct answer to TUCE-28. National statistical results show simular patterns. 
The results from TUCE-28 support the first part of our hypothesis: students are able to answer a set of questions that are designed to test understanding of comparative advantage calculations, specialization, and trade that replicates conclusions consistent with Ricardo’s environment.

\section{Results on the Department Common Comparative Advantage Question}

A part of a department wide final exam in microeconomics contained questions designed to test students' understanding of comparative advantage. These questions were generally written similar to TUCE-28. Table 4 shows the questions and results for each of the four semesters studied. Across the four semesters, approximately $63 \%$ to $80 \%$ of the students answered these comparative advantage questions correctly. These results support the first part of our hypothesis: students are able to answer a set of questions that are designed to test understanding of comparative advantage calculations, specialization, and trade that replicates conclusions consistent with Ricardo’s environment.

\section{Introductory Microeconomics Textbook Coverage of Trade Reasons}

One indication of a systematic treatment of a topic is to see what the typical textbook used as part of the course pedagogical components covers. Of interest is the amount of space given to other reasons for trade in the typical introductory textbook as compared to that given to comparative advantage, specialization, and gains from trade, in the style of Ricardo's two hundred and fifty year-old articulation. Table 5 shows the page count in selected textbooks commonly used in the teaching introduction to microeconomics, in the United States. ${ }^{4}$

Only nine textbooks devote any space to discussing other reasons why trade patterns emerge, with only four of those nine mentioning product differentiation. The discussion of product differentiation, however, generally presents differentiation as a side benefit of trade and not as a motivator for the trade. For example, Mankiw (2015) provides one sentence stating product differentiation as a benefit of trade and not a possible reason why trade may occur. For the books that discuss other scenarios of trade, they generally do not address the specific environment needed to replicate conclusions found in Ricardo’s original illustration. 
In all books the main focus is that comparative advantage is the reason and justification for trade.

Authors devote around 9 pages on average to Ricardian comparative advantage reasoning. This is significantly more than any other discussion and it is clear in the reading that it is the main idea used to explain trade, with no others of any real importance. Clearly the textbooks focus student attention towards comparative advantage reasons for trade and all but ignoring other reasons. In general, the student is left with an idea that comparative advantage is the only driver of and justification for trade, with one country specializing in one good and trading with another whom specializes in a different good.

\section{Conclusion}

As Becker (2007) argued, in addition to students recognizing when the use of comparative advantage is and is not appropriate, it is important for them to learn that economics is not locked into 250 year old ideas. The development of the science of economics has not ignored the dynamics of a changing world. What students see in the realworld must not be disregarded in teaching and testing student learning. Yes, students can memorize the arithmetic, as is demonstrated in this study, but that does not imply that they can appropriately use the concepts of opportunity costs and comparative advantage to properly explain current day trade patterns.

This study looks at one example of a larger pedagogy that is reinforced by momentum, standards, competencies and other rigidities in teaching practices that become entrenched in textbooks and other teaching materials. The main issue is that this systematic approach is miss directed, as demonstrated by the case study in this paper, and has a tendency to leave students with misunderstandings of core ideas in economic and when they can be appropriately applied. ${ }^{5}$

Undergraduate textbooks and principles books, in particular, used to teach basic concepts are rarely adjusted to reflect real-world and current economic research. A remarkable illustration of this can be seen in the principles textbook of Paul Krugman and Robin Wells (2013) where the topic of our current paper is not to be found. Apparently, to meet the norms of the market place the topic of Paul Krugman's 2008 Nobel Prize lecture is absent from the textbook for which he is a co-author. Krugman is not alone, Colander (2004) 
tells how he entered into textbook writing with an ambition to change the way economics is taught, with among other things an emphasis on complexity and dynamic processes. He describes, however, how he was led by reviewers, editors and marketers to follow the standard static framework of market clearing prices and AS/AD. He stated that instructors must recognize that textbooks do not represent what the author knows or believes:

a text(book) is not a direct expression of what the author believes, but instead a combination of a much more complicated set of considerations in which inertia and processes, not intellectual or even pedagogical validity, play the central roles . . . users of the books should be aware that that's what principles of economics textbooks are, and structure their teaching accordingly, adding context to the discussion whenever possible. (p. 39)

Unfortunately, as long as textbooks, standardized tests, and the like are developed to accommodate introductory college courses that are taught as secondary-school courses camouflaged to look like much more, students and society will continue to be short changed. Possibly the stereotypes of the aged, out-of-date professor with yellowed notes and young, ill-informed docents with pre-prepared Power Point slides will continue to prevail, unaffected by advances in the science of economics. 


\section{References}

Becker, William E. (2007). "Quit Lying and Address the Controversies: There Are No Dogmata, Laws, Rules or Standards in the Science of Economics” American Economist, Spring, 3-14.

Becker, William E. (2004). "Economics for a Higher Education,” International Review of Economics Education, Vol. 3 (1), 52-62.

Becker, William E. (2000). “Teaching Economics in the $21^{\text {st }}$ Century,” Journal of Economic Perspectives, Vol. 14, Winter, 109-119.

Berrett, Dan. (2012). “3 Colleges' Different Approaches Shape Learning in Econ 101” The Chronicle of Higher Education June 18.

Colander, D. C. 2013. Microeconomics, 9th ed., New York, NY: McGraw-Hill/Irwin.

Colander, David. 2004. “Caveat Lector: Living with the 15\% Rule.” Australasian Journal of Economics Education, 1 (1): 30-40.

Cowen, T. and A. Tabarrok, 2013, Modern Principles: Microeconomics, 2nd ed., New York, NY: Worth Publishers.

Ferraro, PJ and LO Taylor. 2005. Do Economists Recognize an Opportunity Cost When They See One? A dismal performance from the dismal science. B.E. Journal of Economic Analysis \& Policy (Contributions) 4(1), Article 7.

Feigenbaum, Susan K. and R. W. Hafer, 2012. Principles of Microeconomics The Way We Live, New York, NY: Worth Publishers.

Frank, Robert H., Ben S. Bernanke, and special contribution by Louis D. Johnston, 2009. Principles of Microeconomics, 4th ed., New York, NY: McGraw-Hill/Irwin.

Gottheil, Fred, 2013. Principles of Microeconomics, Mason, OH: South-Western, Cengage Learning,

Hall, Robert E. and Marc Lieberman, 2013. Microeconomics Principles \& Applications, 6th ed., Mason, OH: South-Western, Cengage Learning,

Huynh, Kim P., David T. Jacho-Chávez, and James K. Self (2010). “The Efficacy of Collaborative Learning Recitation Sessions on Student Outcomes,” American Economic Review, 100(2), 287-91.

Krueger, Alan B. and Molly F. McIntosh (2008). "Using a Web-Based Questionnaire as an Aide for High School Economics Instruction,” Journal of Economic Education, 39 (Spring, 2), 174-197.

Krueger, Alan B. (2001). "Teaching the minimum wage in econ 101 in light of the new economics of the minimum wage," Journal of Economic Education, 32 (Summer, 3), 243-258. 
Mankiw, G. N., 2015, Principles of Microeconomics, 7th ed., Stamford, CT, Cengage Learning.

McConnell, Campbell R., Stanley L. Brue, and Sean M. Flynn, 2012. Microeconomics Principles, Problems, and Policies, 19th ed., New York, NY: McGraw-Hill/Irwin.

Parkin, M. 2012, Microeconomics, 10th ed., Boston, MA: Pearson Addison Wesley.

Pashigian, B. Peter and James K. Self, 2007, “Teaching Microeconomics in Wonderland”, Journal of Economic Education, Volume 38, Number 1

Samuelson, Paul A. and William D. Nordhaus, 2010. Microeconomics, 19th ed., New York, NY: McGraw-Hill/Irwin.

Schiller, B. R., C. D. Hill, and S. L. Wall, 2013, The Micro Economy Today, 13th ed., New York, NY: McGraw-Hill/Irwin.

Stiglitz, J. E., C. E. Walsh, 2006, Principles of Microeconomics, 4th ed., New York, NY: W. W. Norton.

Taylor, J. B. 2007, Principles of Micro, 5th ed., Boston, MA: Houghton Mifflin Company. 
Table 1: Percentage of student responding on answer choices to TF-1.

\begin{tabular}{|c|c|c|}
\hline \multirow[b]{2}{*}{$\begin{array}{l}\text { The observation that Germany is importing cars and wine from } \\
\text { France as it is exporting cars and wine to France, suggests that } \\
\text { these trade patterns are the result of Germany's and France's }\end{array}$} & \multicolumn{2}{|c|}{ Fall 2010} \\
\hline & $\begin{array}{c}\text { All } \\
\text { Students* }\end{array}$ & $\begin{array}{l}\text { Self's } \\
\text { Students } \\
\text { only** }\end{array}$ \\
\hline $\begin{array}{l}\text { A. Differing preference for products that each country's } \\
\text { residents demand. }\end{array}$ & $25.7 \%$ & $22.7 \%$ \\
\hline $\begin{array}{l}\text { B. Trade agreements prohibiting specialization within the European } \\
\text { Union. }\end{array}$ & $8.8 \%$ & $6.2 \%$ \\
\hline $\begin{array}{l}\text { C. Equality of opportunity cost in production of their similar } \\
\text { products. }\end{array}$ & $20.3 \%$ & $27.8 \%$ \\
\hline $\begin{array}{l}\text { D. Respective comparative advantage in the production of their } \\
\text { products. }\end{array}$ & $44.8 \%$ & $43.3 \%$ \\
\hline Number of Students & 1,296 & 353 \\
\hline
\end{tabular}

*This represents the department wide aggregation of all students who answered the end of term department wide final exam questions.

**This includes all students in Self's sections who signed the informed consent form and completed the final exam. _ \% of students who completed the Self's course signed the ICF and there was no significant difference in the responses when all of Self's students are included. 
Table 2: Percentage of student responding on answer choices to TF-2.

\begin{tabular}{|c|c|c|c|c|}
\hline \multirow{2}{*}{$\begin{array}{l}\text { The observation that Germany is importing cars } \\
\text { and wine from France as it is exporting cars and } \\
\text { wine to France, suggests that these trade patterns } \\
\text { are the result of Germany's and France's }\end{array}$} & \multirow{2}{*}{$\begin{array}{l}\text { All } \\
\text { Students } \\
\text { Spring } \\
2011^{*}\end{array}$} & \multicolumn{3}{|c|}{$\begin{array}{c}\text { Self's } \\
\text { Students only** }\end{array}$} \\
\hline & & $\begin{array}{c}\text { Spring } \\
2011\end{array}$ & $\begin{array}{c}\text { Fall } \\
2011\end{array}$ & $\begin{array}{c}\text { Spring } \\
2012\end{array}$ \\
\hline $\begin{array}{l}\text { A. equality of opportunity costs in production of } \\
\text { their similar products. }\end{array}$ & 24 & 24.5 & 25.6 & 25.6 \\
\hline $\begin{array}{l}\text { B. respective comparative advantages in the } \\
\text { production of their products. }\end{array}$ & 30.5 & 24.5 & 18.4 & 18.2 \\
\hline C. Options A and B are correct. & 23 & 24.5 & 43.2 & 41.9 \\
\hline D. Options A, B and C are not correct. & 19.5 & 26.5 & 12.5 & 14.3 \\
\hline Number of Students & 1,142 & 151 & 374 & 203 \\
\hline
\end{tabular}

*This represents the department wide aggregation of all students who answered the end of term department wide final exam questions.

**This includes all students in Self's sections who signed the informed consent form and completed the final exam. Between__\% and __ of students who completed the Self's course signed the ICF and there was no significant difference in the responses when all of Self's students are included for any term. 
Table 3: Percentage of student responding on answer choices to TUCE-28.

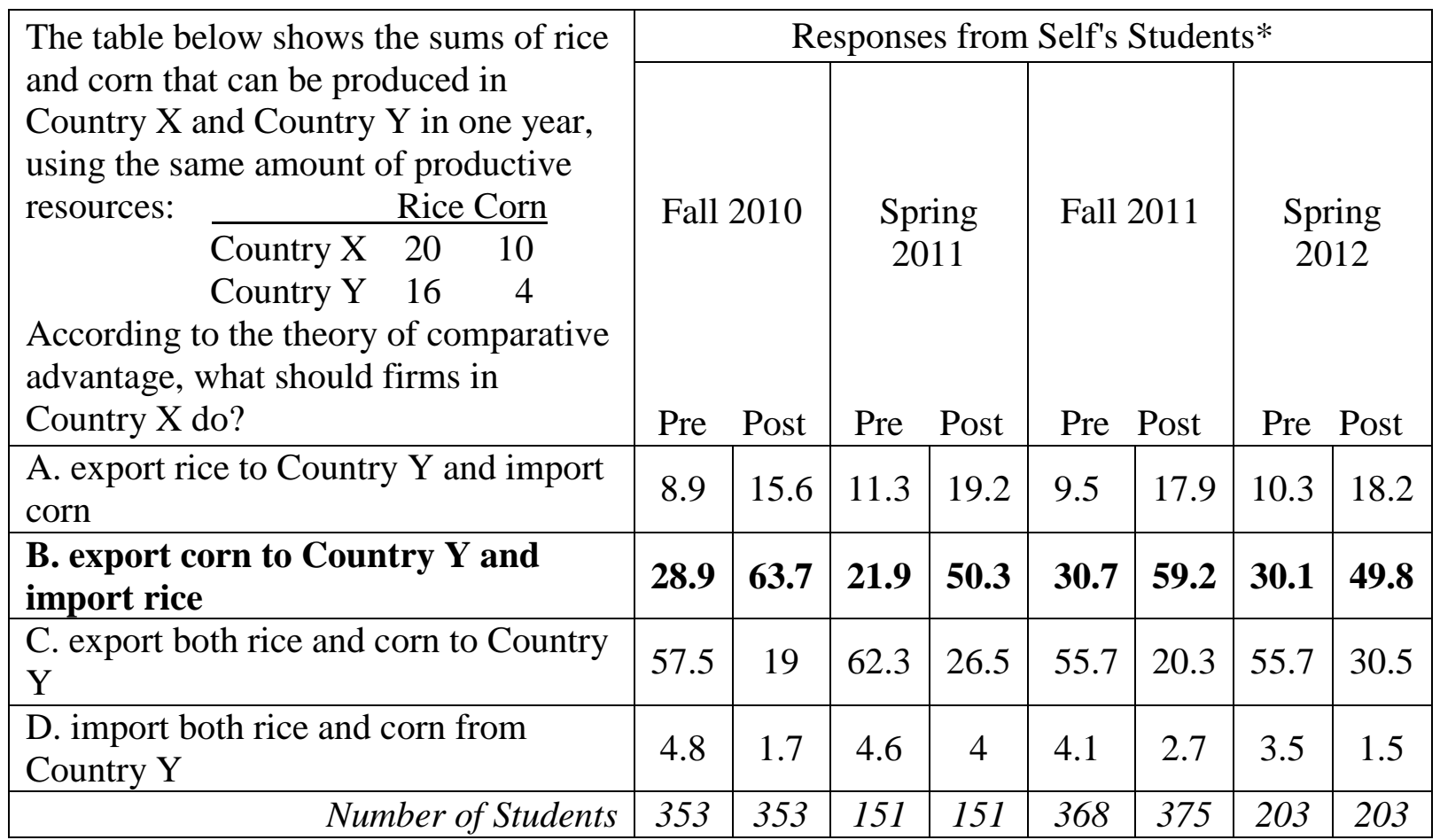

*This includes all students in Self's sections who signed the informed consent form and completed the final exam. _ \% of students who completed the Self's course signed the ICF and there was no significant difference in the responses when all of Self's students are included. 
Table 4: Department Common Comparative Advantage Question Results

\begin{tabular}{|c|c|c|c|c|}
\hline \multicolumn{5}{|c|}{ Fall 2010} \\
\hline $\begin{array}{l}\text { Ken } \\
\text { Debbie } \\
\text { The information } \\
\text { Debbie. Based }\end{array}$ & $\begin{array}{l}\text { Popcorn } \\
5 \text { bags per hour } \\
20 \text { bags per hour } \\
\text { in the table above s } \\
\text { n the information i }\end{array}$ & $\begin{array}{l}\text { production capabilities for Ken and } \\
\text { table, we can say that }\end{array}$ & $\begin{array}{c}\text { All } \\
\text { Students* }\end{array}$ & $\begin{array}{l}\text { Self's } \\
\text { Students } \\
\text { only }\end{array}$ \\
\hline \multicolumn{3}{|c|}{$\begin{array}{l}\text { A. Ken has an absolute advantage in the production of fruit punch and a } \\
\text { comparative advantage in the production of popcorn. }\end{array}$} & $5.56 \%$ & $6.33 \%$ \\
\hline \multicolumn{3}{|c|}{$\begin{array}{l}\text { B. Ken has both an absolute advantage and comparative advantage in the } \\
\text { production of fruit punch. }\end{array}$} & $76.08 \%$ & $74.41 \%$ \\
\hline \multicolumn{3}{|c|}{$\begin{array}{l}\text { C. Debbie has both an absolute advantage and comparative advantage in the } \\
\text { production of fruit punch. }\end{array}$} & $2.01 \%$ & $1.06 \%$ \\
\hline \multicolumn{3}{|c|}{$\begin{array}{l}\text { D. Debbie has an absolute advantage in the production of popcorn and a } \\
\text { comparative advantage in the production of fruit punch. }\end{array}$} & $11.11 \%$ & $13.72 \%$ \\
\hline \multicolumn{3}{|c|}{$\begin{array}{l}\text { E. Debbie has an absolute advantage in the production of fruit punch and a } \\
\text { comparative advantage in the production of popcorn. }\end{array}$} & $5.17 \%$ & $4.49 \%$ \\
\hline & & Number of Students & 1296 & 379 \\
\hline
\end{tabular}

\section{Spring 2011}

Suppose Mark and Michael start a business together that repairs computers and installs anti-virus software. Mark can repair 20 computers per day or install software on 15 computers per day. Michael can repair 10 computers per day or install software on 5 computers per day. Michael has __ advantage in__. To efficiently use resources, Michael should specialize in A. a comparative; repairing computers; installing software

B. an absolute; repairing computers; repairing computers

C. a comparative; repairing computers; repairing computers

D. an absolute; installing software; repairing computers

E. a comparative; installing software ; installing software

All

Students*

Self's

Students

only

$$
\text { Number of Students }
$$

\section{Fall 2011}

John and Mary both produce only burgers and tacos. In five minutes, John can produce 2 burgers or 4 tacos. In five minutes, Mary can produce 3 burgers. Unfortunately, Mary has not made tacos in a long time and is unsure how many she can make in five minutes. However, suppose you know that John has a comparative advantage in making tacos. Based on this information, which of the following could correctly represent the maximum number of tacos that Mary could make in five minutes?

\begin{tabular}{|l|l|l|}
\hline A. 3 & $17.49 \%$ & $22.38 \%$ \\
\hline B. 4 & $4.46 \%$ & $4.38 \%$ \\
\hline C. 5 & $64.02 \%$ & $63.02 \%$ \\
\hline D. 6 & $5.17 \%$ & $3.41 \%$ \\
\hline E. 7 & $8.78 \%$ & $6.57 \%$ \\
\hline
\end{tabular}


Table 4 Continued ...

\begin{tabular}{|l|l|l|}
\hline \multicolumn{3}{|c|}{ Spring $\mathbf{2 0 1 2}$} \\
\hline $\begin{array}{l}\text { Suppose that Illinois can produce 1 unit of cheese and 3 units of bread per } \\
\text { hour. Indiana can produce 3 units of cheese and 5 units of bread per hour. } \\
\text { We can infer that: }\end{array}$ & $\begin{array}{l}\text { All } \\
\text { Students* }\end{array}$ & $\begin{array}{l}\text { Self's } \\
\text { Students } \\
\text { only** }\end{array}$ \\
\hline $\begin{array}{l}\text { A. Illinois has a comparative advantage in the production of cheese, and } \\
\text { Indiana has a comparative advantage in the production of bread. }\end{array}$ & $11.33 \%$ & $14.41 \%$ \\
\hline $\begin{array}{l}\text { B. Illinois has a comparative advantage in the production of neither good, } \\
\text { and Indiana has a comparative advantage in the production of both goods. }\end{array}$ & $7.95 \%$ & $11.26 \%$ \\
\hline $\begin{array}{l}\text { C. Illinois has a comparative advantage in the production of both goods, and } \\
\text { Indiana has an absolute advantage in the production both goods. }\end{array}$ & $5.49 \%$ & $9.46 \%$ \\
\hline $\begin{array}{l}\text { D. Illinois has a comparative advantage in the production of bread, and } \\
\text { Indiana has a comparative advantage in the production of cheese. }\end{array}$ & $74.73 \%$ & $64.41 \%$ \\
\hline $\begin{array}{l}\text { E. Illinois has an absolute advantage in the production of both goods, and } \\
\text { Indiana has a comparative advantage in the production of neither good. }\end{array}$ & $0.51 \%$ & $0.45 \%$ \\
\hline Number of Students & 1183 & $222^{*}$ \\
\hline
\end{tabular}


Table 5: Pages Devoted to Comparative Advantage and Other Reasons for Trade

Col. (1): Textbook

Col. (2): Total Pages Devoted to Comparative Advantage, Specialization, and Gains From Trade (in the style of David Ricardo (1772-1823) articulation)

Col. (3): Pages Devoted to transferable Comparative Advantage and benefits from trade

Col. (4): Pages Devoted to Intra-industry trade and Larger Markets Reasons for trade

Col. (5): Pages Devoted to consumer preference reasons and product differentiation Reasons for trade

\begin{tabular}{|c|c|c|c|c|}
\hline (1) & (2) & (3) & (4) & (5) \\
\hline Colander (2013, 9th Ed.) & 7.5 & 1.5 & 2 & 0 \\
\hline Cowen and Tabarrok (2013, $\left.2^{\text {nd }} E d.\right)$ & 8 & 0 & 0 & 0.75 \\
\hline Feigenbaum and Hafer (2012) & 7 & 0 & 0 & 0 \\
\hline Frank and Bernanke (2009, $4^{\text {th }}$ Ed.) & 9 & 0 & 0 & 0 \\
\hline Gottheil (2013) & 9 & 0 & 0 & 0 \\
\hline $\begin{array}{l}\text { Gwartney, Stroup, Sobel, and Macpherson } \\
\left(2015,15^{\text {th }} \text { Ed.) }\right.\end{array}$ & 8.25 & 0 & 1 & 0 \\
\hline Hall and Lieberman (2013, $6^{\text {th }}$ Ed.) & 13 & 2.5 & 0 & 0 \\
\hline Hubbard and O’Brien (2015, $5^{\text {th }}$ Ed.) & 10.75 & 0.25 & 0.25 & 0.25 \\
\hline Karlan and Morduch (2014) & 10.75 & 0.25 & 0 & 0 \\
\hline Krugman and Wells (2013, $3^{\text {rd }}$ Ed.) & 9.5 & 1.75 & 0 & 0 \\
\hline Mankiw (2015, $7^{\text {th }}$ Ed.) & 12.5 & 0 & $0.1^{*}$ & $0.1^{*}$ \\
\hline Mateer and Coppock (2014) & 7 & 0 & 0 & 0 \\
\hline McConnell, Brue, and Flynn (2012, $19^{\text {th }}$ Ed.) & 8.5 & 0 & 0 & 0 \\
\hline Parkin (2012, $10^{\text {th }}$ Ed.) & 7.5 & 0 & 0 & 0 \\
\hline Samuelson and Nordhaus (2010, $19^{\text {th }}$ Ed.) & 8.25 & 0 & 0.5 & 0.25 \\
\hline Schiller, Hill, and Wall (2013, $13^{\text {th }}$ Ed.) & 7 & 0 & 0 & 0 \\
\hline Stiglitz and Walsh $\left(2006,4^{\text {th }}\right.$ Ed.) & 7.5 & 0 & 0 & 0 \\
\hline Taylor (2007, $5^{\text {th }}$ Ed.) & 12 & 1 & 7.5 & 0 \\
\hline
\end{tabular}

*One sentence stated as a benefit and not a reason for trade. 


\section{Endnotes}

\footnotetext{
${ }^{1}$ Ferraro and Taylor (2005) report on economists attending the Allied Social Science Association meetings not being able to correctly identify the opportunity cost in the following hypothetical situation:
}

You won a free ticket to see an Eric Clapton concert (which has no resale value). Bob Dylan is performing on the same night and is your next-best alternative activity. Tickets to see Dylan cost $\$ 40$. On any given day, you would be willing to pay up to $\$ 50$ to see Dylan. Assume there are no other costs of seeing either performer. Based on this information, what is the opportunity cost of seeing Eric Clapton?

They conclude that although the concept of opportunity cost is covered in the first week of an introductory undergraduate course, it is incorrectly deemed to be so straightforward as to not require further teaching time. They also observe that it is not contained in graduate textbooks and clearly should be. They quote a survey responder from a top-20 Ph.D. economics program saying: "When would I have learned the concept of opportunity cost? I don't remember hearing that word used in graduate school.”

Could it be that the old idea of opportunity cost is too simplistic to have any true meaning in real decision making? Could it be that the science of economics has moved beyond this simplistic bivariate relative pricing idea? Could it be that graduate textbooks, as in my presentation on the shadow prices of teaching and research, have correctly given up on the introductory economics course idea of an opportunity cost in favor of more useful measures of price? Alternatively, why is there such a divide between undergraduate and graduate education in economics? Could it be that those at the forefront of research in economics and teaching in prestigious graduate programs are misleading their students? These are not rhetorical questions - we seriously do not have the answers.

${ }^{2}$ In addition to TF-1 and TF-2 a prototype question was administered to one section of students which yielded similar results as the final questions. Below is wording of the question.

The observation that Germany is importing Peugeot cars from France at the same time it is exporting Volkswagens to France, suggests that this trade pattern is the result of Germany's and France's respective
A. comparative advantage in the production of their cars.
B. differing preference for cars that each country's citizens demand.
C. equality of opportunity costs in car production.
D. trade agreements prohibiting specialization within the European Union. 
${ }^{3}$ See Huynh, Jacho-Chávez, and Self (2010) for the design of these course sections.

${ }^{4}$ To ensure the page counts represents typical instructor interpretation of the content, independent counts were made by three advanced Ph.D. graduate students at Indiana University who had at least a couple of years' experience teaching introduction microeconomics. Appendix A, provides their counts. Most difference in their counts and the authors of this paper are in the interpretation of the examples used in the pages counted and in some cases other sections of the textbook that covered topics but were not fully included in their counts. In each case the same pattern emerges as that found with the authors page counts.

${ }^{5}$ This rigidity of content and teaching methods is not unique to the principle courses. Peter B. Pashigian and James K. Self (2007) point out a miss allocation of topic space of competitive markets and non-competitive markets in intermediate microeconomic textbooks and are replicated in general teaching practices in intermediate microeconomic courses. In the same study, it is also pointed out of the prevalence of generally unaccepted ideas such as the kinked demand curve still being used in the textbook discussions of oligopolies. This pattern is consistent with a pattern seen in the principle textbooks. 